\title{
MONGOL-SINO ECONOMIC RELATIONS AND COOPERATION IN THE NEW AGE OF GLOBALIZATION
}

\section{Shurkhuu Ph.D. (Mongolia)}

Globalization and its impact is one of the most discussed issues of contemporary international relations. Today's world economy is in the midst of powerful change leading in the direction of globalization and borderless system of economic transactions. This has been made possible by the former socialistbloc countries eagerly promoting the transition to free market economies, by the rapidly modernization of China and the countries of Southeast Asia, and by the extraordinary development of information and communications technology.

Indeed what does globalization mean? Is it process or policy? Who are the beneficiaries? Who is against? Who favors globalization?

We see a variety of definitions, terms, and ideas in the debate over globalization presented by people with different worldviews and perceptions. Some people, like corporate globalists, see progress everywhere. From their vantage point, the drive to privatize public assets, freeing the market from governmental interference, appears to spread freedom and prosperity throughout the world, improving the lives of people everywhere and creating the financial and material wealth necessary to end poverty and to protect the environment. The others, like citizen movements, see a starkly different reality. They see a world in deepening crisis of such magnitude as to threaten the fabric of civilization and the survival of the species - a world of rapidly growing inequality, erosion of relationships of trust, and failing planetary life support systems. They see globalization replacing democracies of people with democracies of money, self-organized markets with centrally planned corporate economies, and diverse ethical cultures with cultures of greed and materialism. ${ }^{1}$

U.S. Trade Representative Robert B. Zoellick notes in his April 9 speech at Central University of Finance and Economics in Beijing, that:

- Globalization is not a new phenomenon. Each new era of globalization has its own unique characteristics.

- Globalization is an objective trend, akin to a force of nature. It can sweep aside antiquated and dysfunctional customs, institutions, and ways of thinking. It is not something that can be stopped by a leader or a nation.

${ }^{I}$ http://www.ifg.orp/pubs.htm. A Better World Is Possible! Alternatives to Economic Globalization. 
- Globalization may be a force, but it need not be a blind force if shaped and directed. Nonetheless, ideas matter, leaders matter, and people matter. All of us - each of you - can help shape the future. We can preserve valuable traditions and blend the old with the new.

- Globalization can bring extraordinary benefits to peoples and nations, both tangible and intangible - ideas, reforms, goods, investments, and even necessary revolutions.

As Professor Stephen Noerper notes in his article "Globalization and Integration," through discussions we have journeyed to distant lands and understand better the new terrains of this increasingly globalize and integrated world. ${ }^{2}$

\section{Globalization and Mongolia}

Economic globalization is an irreversible trend no country in the world can resist. Despite various looming challenges and risks, the globalization process also provides an historical opportunity for developing countries, including Mongolia - a country with a small and vulnerable economy and a population of 2.4 million living in a vast territory - to advance their national economy. Economic globalization has pushed to the forefront the contradiction between ecological environmental protection and sustained economic development of developing countries.

Clearly, worldwide economic globalization will not necessarily lead to global common prosperity. The world wealth created in the process will fall into the hands of a handful of developed countries and transnational corporations, a majority of nations will still face the likelihood of being marginalized. Therefore, we should take active measures to embrace the economic globalization process for own economic prosperity in an increasingly poor international economic climate.

While having to find better ways to participate in the integration process, we also should develop and exploit our own following competitive advantages:

- A stable political environment and an open economy

- A strategic easy access to the giant markets of Russia and China

- Extensive natural resources

- A favorable legal environment

- Young, educated population

- A vast territory with a clean and undisturbed nature

${ }^{2}$ The Mongolian Journal of International Affairs, No7, 2000. P-11 
- Vast opportunities for new industry and expansion

Meanwhile, Mongolia faces problems similar to all other small vulnerable economies. For example:

- An excessive dependence on foreign trade. The volume of foreign trade equals to $120 \%$ of the GDP.

- A lack of economic diversification: $82.6 \%$ of export earnings and 61.7 of import purchases of Mongolia belong to only three major items of export and import.

- An excessive dependence on external sources of financing. Foreign assistance and loans still make up over $10 \%$ of the GDP of Mongolia. ${ }^{3}$

Compared to other countries in transition, Mongolia has achieved tangible results in trade liberalization. Mongolia's accession to the WTO in January 1997 highlights its relative success in pursuing economic reforms and developing a new trade regime in line with international trading principles.

\section{Globalization and China}

How best to bolster the benefits and mitigate the risks of globalization remains a subject of considerable debate among policy makers, business people, scholars, and citizens in China. Li Hongbao, professor of Jiling University, points out that "The most discussed issues in the debate over globalization in China are such as four aspects: globalization and government power and sovereignty; national economic security; transnational corporations and national economy, and international economic order."4

Since China adopted its reform and open policy two decades ago, robust economic growth has translated into dramatically improved living standards for the Chinese people. According to quoting figures issued by the World Trade Organization (WTO), China's total goods imports and exports in 2001 reached 509.8 billion US\$, with exports at 266.2 billion USS and imports 243.6 billion US\$. The imports and exports both stood in sixth position among the top ten trading nations of the world. China's foreign trade volume ranked the eleventh in 1998, and tenth in 1999. Total world exports last year totaled 6,162.4 billion USS, down 4.1 percent from 2000 while total imports declined 3.9 percent to $6,438.8$ billion US\$.

${ }^{3}$ The lecture of PM of Mongolia N. Enkhbayar at the Foreign Policy Association on "Mongolia in the Age of Globalization". Jan. 31, 2002 New York - "External Relations" Bulletin of Ministry of External Relations, Mongolia. No3, 2002

${ }^{4}$ North East Asia Forum, Nov.2001, N4, p-81 
China's international trade's previous peak was in 1928, when it equaled $2.3 \%$ of the world total - a level it would not surpass in the next 65 years. In the intervening period, its share of world trade fell to a low of $0.6 \%$ in $1977 .{ }^{5}$

Following the trend of economic globalization, the world economy has become vastly more complex and interconnected, so China's participation in it, according to the rules of international trade, has become that much more critical for China, as well as for Asia, and the world. Chinese vice Premier Li Lanqing told the 2002 Business Week Forum in Tianjin last May that China's prosperity is impossible without the world and global development, which is difficult without China.

China's accession to the WTO on December 11, 2001, is the latest important step enabling China to navigate globalization's currents. WTO entry means both opportunities and challenges. Chinese leaders have said many times that China will strictly abide by WTO rules and earnestly fulfill its pledges. The six major obligations China is to bear following its WTO entry are $^{6}$ :

China is to treat each WTO member equally. All individuals and organizations involved in foreign investment will enjoy at least the same treatment as Chinese enterprises regarding the rights of trade.

- China is to abolish the practice of double-track pricing as well as different treatments for domestically sold goods and exported goods.

- Price controls will not provide protection for domestic manufacturers and service companies.

- China is to modify existing domestic legislation and draft new laws in a unified and effective manner in line with the WTO Agreement; also to meet requirements of the WTO Agreements.

- Three years after China's WTO entry, except for handful of cases, all enterprises will have the right to import and export goods and conduct trade within the customs territory.

- Farm products will have no export subsidies of any sort.

After China fulfils all its pledges, its average tariff on farm products will drop to 15 percent, while tariffs of Industrial goods will be reduced from 25 percent to 7 percent.

Chen Qingtai, deputy director of the Development and Research Center (DRC) in the State Council, says that following China's WTO entry, some key

\footnotetext{
${ }^{5}$ http://www.TheGlobalist.com/ Globalize Factsheet

${ }^{6}$ China Daily, October 27-28, 2001
} 
fields can enjoy a transitional period, which is common practice among WTO members. The transitional period, however, should not be regarded as a protection period. Instead, it is a training period for industry competitiveness and a period to accelerate government reform.

The WTO rules will protect China's rights, and the expectations of its exporters, against damaging protectionist policies in overseas markets. China's vulnerability to discriminatory, ad hoc protectionism in its major export markets has grown, along with China's success in increasing its exports over the past 20 years.

\section{Mongol-Sino Economic Relations and Cooperation}

During Mongolian Prime Minister's visit to China in the beginning of 2002, N. Enkhbayar and his Chinese counterpart noted that they were satisfied with the rapid development of the relationship between Mongolia and China. By 2000, 35 percent of ( $\$ 376.6$ million) total revenue from foreign trade came from China. Since 1990, by the end of 2001, there more than 2,000 joint ventures and foreign-owned companies from over 70 countries have been registered in Mongolia. The total foreign invested registered capital amounts over US\$ 600 million, including oil sector investment. China is Mongolia's major investing country as measured by invested capital and the number of companies. ${ }^{7}$

\section{Mongol - Sino Trade Turnover}

$(\$ m \ln$.

\begin{tabular}{|l|c|c|c|c|c|c|}
\hline & 1990 & 1995 & 1998 & 1999 & 2000 & 2001 \\
\hline Turnover & 33.6 & 112.5 & 159.6 & 273.5 & 376.6 & 314.1 \\
\hline $\begin{array}{l}\text { Percentage of } \\
\text { total turnover }\end{array}$ & $2 \%$ & $13.8 \%$ & $19 \%$ & $31 \%$ & $35 \%$ & $33.4 \%$ \\
\hline Export & 11.3 & 73.24 & 101.1 & 232.0 & 267.1 & 206.8 \\
\hline $\begin{array}{l}\text { Percentage of total } \\
\text { export }\end{array}$ & $1.7 \%$ & $14.3 \%$ & 29.3 & $57 \%$ & $57 \%$ & $53.7 \%$ \\
\hline Import & 4.9 & 39.38 & 58.5 & 94.3 & 109.5 & 107.3 \\
\hline $\begin{array}{l}\text { Percentage of total } \\
\text { import }\end{array}$ & & $10.1 \%$ & $11.6 \%$ & $18.3 \%$ & $17 \%$ & $19.3 \%$ \\
\hline
\end{tabular}

Source: Yearbooks of National Statistics Office of Mongolia

The conditions that have impact on the successful economic relationship between the two countries include:

\footnotetext{
${ }^{7}$ http://www.investmongolia.com
} 
- There is no ongoing political tension between the two countries. Traditional high level official visits and meetings play a vital role in the deepening the mutual understanding and relationship;

- The economies of both countries are opening their markets in accordance with the principles of globalization;

- China has granted constant soft loans and irrevocable aid (totaling 450 million Chinese Yuan);

- Border trade and cooperation have improved due the geographical close distances, mitigation in border entry regulations for the citizens of both sides, and opening of 10 border posts;

- The frame of corporate and joint ventures has expanded with the exploitation of useful mineral deposits, establishment of hydro power stations, building and repairing roads, and building apartments;

Although the trade and economic relations between Mongolia and China have improved immensely, there are still a number of questions that require attention. There are also unexploited opportunities and resources.

Trade. There are serious obstacles that may threaten the economic security of Mongolia. The trade statistics and index of the two countries show that export products of strategic importance, such as copper, cashmere, skin, hide, and their market are getting very dependent on China. Approximately 94 percent of copper concentrate, 100 percent of molybdenum concentrate, and most of the raw cashmere, skin and hides, and 49.5 percent of processed cashmere are exported to China ${ }^{8}$ Because of the nature of Mongolia's exports, which lacks a variety and is comprised mostly of useful minerals and raw materials, the foreign trade gain may reduce. There is a risk that Mongolia may become a raw material purveyor of a foreign country. Exports to China have dramatically increased over the past few years because Western trade companies and ventures started to process the minerals and materials in China. Therefore, the variety and amount of export remains relatively the same except for copper concentrate. According to official statistics, provided by the Central Customs Office of Mongolia, agricultural products still dominate Mongolian export. From 1993-1999, 27.7 million animal skins and hides were exported to China. This included 17.7 million sheepskins, 5.8 million goat skins, 2.6 million cow hides, 1.3 million horse hides, and 150,000 camel hides. ${ }^{9}$

\footnotetext{
${ }^{9}$ Galsandorj. D, Bud.H. "Brief History of Mongolia's Foreign Economic Relations. (1921-2000)" Ulaanbaatar, 2001, p. 184

${ }^{9}$ Mongolia-Sino Relations: The Questions about Socio-Economic Situations (90s of XX Century), Ulaanbaatar- 2001. p-38-39
} 
Food products, consumer goods, and appliances comprise the majority of Mongolia's imported products. The main products, flour, rice, sugar, fruits are imported from China, threatening Mongolia's food security.

China's borders with 15 countries including the Russian Federation, Mongolia, North Korea, and Kazakstan about 20 thousand km. Noteworthy is that the borders with Mongolia total 4,677 kilometers. For the past few years, although there has been promising development, there are still tensions and problems that occur over payment, supply, quality or the price of products between the sides. Furthermore, because of the poor conditions of the border posts and lack of control, illegal acts, such as tax avoidance and smuggling, take place. Although it appears as if it is between small companies, ventures, and individuals, it affects the reputation and mutual confidence of both sides and the foreign trade. Therefore, from our side, it is vital to create a favorable condition for border trade, from the top down, putting foreign trade acts in order and improving the conditions of border posts.

Investment, Banking and Finance. The investment of China in Mongolia lead all other countries by size of invested capital and number of companies since 1990. But there are some problems that should be brought to attention. The quality, profit results, and size of China's investment are low compared to the trade turnover and potential of the two countries. The average size and amount of investment from China is below average of country $(240,000$ US\$ per project), and so far there is no company that can contribute significantly to the state budget and exports. The Foreign Investment and Foreign Trade Agency has announced the list of top investors in Mongolia for the first time. Investors are listed according to the amount of investment they made and their business success. Only one company from China is in the bottom of that list. There is no company among China's invested companies and JVC that invested more than 1 million US\$. If we include in our calculation such giants as JVC Erdenet mining, Rostsvetmet mining, and Ulaanbaatar railway, it easy to find that the share and influence of investment from China in the Mongolian economy is very small. The reasons for no strategically important investments in Mongolia from China are lack of developed infrastructure, small size of the market, and because of the language barrier, information about Mongolia's investment environment has been reaching the large companies of China. Additionally, Mongolians harbor longstanding concern about the possibility of China's increasing political and economic influence in Mongolian society, i.e., a distinct distrust of China. China's vulnerability to discriminatory, ad hoc protectionism in its export market and 
investment in Mongolia has grown, along with China's success in increasing its exports over the past 10 years. During his visit to Mongolia in July 1999, the president of China, Jingo Seeming, in order to expand the trade and economic cooperation, proposed five suggestions, including an item to improve investment environment and protection of legal rights of investors ${ }^{10}$.

The situation of small Chinese companies and individuals involved in Mongolian business activity without clear purpose and operation that might influence negatively on the future investments from China, must be cleared and regulated by a certain and determined policy. However, we should work actively to attract serious investors from developed regions and cities of China and Hongkong.

The sectors that has fallen behind the most in the economic relationship of Mongolia and China, is finance, banking, payment and transaction. There is information that and amount of money equal to $30-40 \%$ of Mongolia's GDP, is circulating outside the banking system ". It is not clear in whose hands this large sum of money is and whose interest is it serving. It is not difficult to see from life that Chinese individuals and small companies are also getting involved and contributing to this situation. For example, from a study done at "Naiman sharga" currency exchange free market, every month from average the transaction of 6.1 billion tug rugs, 57 percent is Chinese Yuan. ${ }^{12}$ The illegally entered foreign currency might seriously influence economic security. Because this is becoming the main contributor and encourager for an underground economy, it weakens the money management and control, besides the negative impact on taxation. To reduce this negative phenomenon, it is essential to develop Chinese and Mongolian cooperation in the field of finance and banking, to modernize the payment and transaction, and to improve the inter-state banking services.

Mongolia is steadily entering a stage to hasten its economic development, overcoming the obstacles of the transition period to a market economy. Mongolia has succeeded significantly at developing its industry and infrastructure, and attracting foreign investment to the fields. There is a tendency that mining and exploiting of oil, gold, copper, coal, silver and their output will increase. As for the PRC, it is necessary to keep a reliable source of fuel, electricity, and raw

\footnotetext{
${ }^{10}$ Chang Wanlong and Wang Yimin. Retrospect and Prospect of Sino-Mongolian relations. Euro-Asia social development studies. Annually. 2001. N7 , p-107-112

${ }^{11}$ D.Tungalag,D.Tserenpil. Some Issues on Mongolia's Economic Security. Ulaanbaatar, 2002. P-143

${ }^{12}$ D.Tungalag,D.Tserenpil. Some Issues on Mongolia's Economic Security. Ulaanbaatar, 2002. $P-144$
} 
materials both domestically and abroad to ensure steadfast economical development. China is, however, expected to experience a large deficit of raw materials in the coming 20 years. According to official forecasting, of its 45 major mineral resource categories, the annual output of 14 will only satisfy the country's needs to 2010. And in 2020, the figure will decrease further to just six..$^{13}$

On the other hand, large foreign investments to Mongolia must first consider the markets of the two giant neighbors. The entry of China in the WTO this year as the 143rd member has increased the worldwide market, investment, and trade interests for China. WTO membership and the right to organize 2008 summer Olympiad will definitely affect the China's market and economic development positively, which will ultimately have an impact on the Mongolian economy as a neighboring country.

In light of the above mentioned domestic and external new situations and circumstances of the two countries, it is increasingly becoming clear that the mining industry will be the most successful industry for the trade and cooperation between Mongolian and China.

Oil. The oil consumption of China reached 200 million tons last year, and this figure is expected to reach 300 million by 2010. China will, however, be able to meet only $60 \%$ of its demand domestically and import the rest. ${ }^{u}$ On the other hand, Mongolia has discovered a large deposit of natural oil in the Droned aimag in the Tamsag valley.

Copper. Although $10 \%$ of world's domestic production goes to China, the copper consumption of China is expected to steadily increase and reach 2.6 million by 2010. Last year, China imported 520,000 tons of copper from Chile, and it may become necessary to rent mines abroad and establish joint ventures to ensure further supply. On the flip side, copper is one of the major export products of Mongolia. In addition to Erdenet mining, efforts are underway to mine newly discovered mining deposits and to direct foreign investment to them. The Tsagaan-Suvraga deposit, located $164 \mathrm{~km}$ southwest of the Zuun-Bayan railroad station, is in the semi-desert, unpopulated and water scarce region of Southeast Mongolia. Commercial ore reserves of the deposit have been estimated at $220-240$ million tons. The gold and copper reserves of the Oyutolgoi deposit, situated in Khanbogd soum, Umnugovi aimag, are estimated to have reserves of 3.2 million tons of copper and 448.7 tons of gold.

In recent years, cooperation between Mongolia and China in the infrastructure sector has becoming very active, and there are more opportunities and

${ }^{13}$ China Daily. November 17-18, 2001

${ }^{14}$ China Daily. Oct.25, 2001. 
resources to expand and intensify. China is participating in projects such as Dorgon Hydro Power Plant in Hovd aimag (Loan of the Chinese side is 26.5 million US\$) asphalt covered road maintenance from Erdenesant toTsetserleg, to build an asphalt covered road of $200 \mathrm{~km}$ from Nalaikh to Choir. There is an ongoing study at the government level of the two countries on the possibility of cooperation in large projects, such as, implementing the "Millennium Road Project" (construction of network of $2.500 \mathrm{~km}$ of road crossing Mongolia from East to West and connecting it by road with its neighbors and the rest of the world), to connect City of Choibalsan and Arshaant with a railway, and to build a grid between Erdenet and Murun.

Interested sides are studying and discussing the unified electric grid for Northeast Asian countries. If participating sides can get reach an agreement, a unified grid will be built by connecting large hydro power plants in Russian Siberia with the Chinese high voltage grid. Power grid costs less than natural gas pipeline, and it is also easier to satisfy the safety and maintenance requirements. For aforementioned reasons, there is a greater possibility that a power grid line will go through our country.

In terms of the telecommunication sector, our country is getting connected from Naushka to Zamiin Uud along the railway and a fiberglass cable network between Russia and China. Furthermore, there is ongoing work on connecting with fiberglass cable from Ulaanbaatar to Choibalsan, and to Hyangan Aimag of Inner Mongolia, and Jiling province of China with a foreign loan and aid. It is certain that these ongoing and future projects will give a push to the two side's cooperation; it will show a great influence to develop regional integration.

Tourism is another branch economy with broad future in Mongolia and China cooperation. There are two ways to collaborate. First, encourage travel of people of two countries. Second is mutual investment in the tourism industry to operate transnational tourism. According to official figures of China, in 2000, among 10.2 million foreign tourists who visited China, about $4 \%$ or 399,100 were citizens of Mongolia. Mongolia was seventh among top ten countries in the number of visitors to China. The average total expenditure per visitor from Mongolia was 377 US\$ per person a day. ${ }^{15}$ from this calculation, our people who visited China, about 151 million US\$ were contributed to China. In 2000, from 158,000 foreign passengers entered through Mongolian border posts, 58,300 were from China. Some researchers estimated that a Chinese tourist spends an average 33 USS a day. China is large country with 1.3 billion people, and the largest tourism market in the world. There is great opportunity to develop coop-

${ }^{15}$ HTTP// www: cnta.eov.cn 
eration of China and Mongolian international tourist industry, and certainly the new membership of China in WTO, will give positive influence. Development of tourism activity in Central Asian, European, Southeast and Northeast Asian countries by taking full advantage of geographic location as a bridge between Europe and Asia, and relying on large Chinese tourism market, will present a great opportunity to expand tourism.

These facts show a potential for further long-term trade and corporation between the two countries. Only mutually respectful policy and efforts with long term visions, and right implementation will ensure the best outcome.

\section{Conclusion}

Depending on how the country deals with the opportunities and challenges in the globalization process, the economic relationship between Mongolia and China in the coming 20-30 years can be seen from two perspectives.

The first perspective is an optimistic one. China will continue to develop and become the core of the world's trade and industry. Following the progress, a possibility opens for Mongolia to integrate more closely with the world economy through China to Asia and the Pacific. The market for pure ecological and mineral products and raw materials will continue to increase. To meet the market needs of China and the world, Mongolia's geographical situation connecting Asia and Europe will play a greater role. These forces will have a greater role, hastening the social and economical development of Mongolia and improve the people's living conditions significantly.

The second perspective is less optimistic. It is possible that Mongolia will become more heavily dependent on the Chinese market. In this picture, Mongolia will be left out of the world's market and regional integration because of the clashes between the two countries and the economical ambitions of super powers and multinational corporations to impose their influence in the country. There will be other negative results of globalization that will also play a significant role. Ecological imbalance due to the massive consumption of minerals and raw materials, the possibility of getting involved in cross national organized crime, deterioration of the independent nature of the country, poor development progress, and living conditions may cause a stronger resentment against foreign involvement in the affairs of the country, especially that of China, and ultimately affect the relations between the two nations.

It is, however, essential for the two countries not to repeat the mistakes of the past, but instead to seek solutions to mutual problems and to work together for economic development. 